\title{
ON SOME BOOKS AND THEIR ASSOCIATIONS.
}

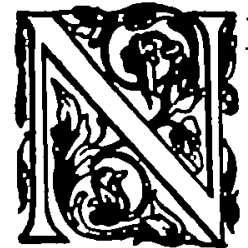

EW books can have few associations. They may come to us on the best deckle-edged Whatman paper, in the newest founts of famous presses, with backs of embossed vellum, with tasteful tasselled strings; and yet be no more to us than the constrained and uneasy acquaintances of yesterday. Friends they may become to-morrow, the day after,-perhaps hunc in annum et plures. But for the time being, they have no part in our past of retrospect and suggestion. Of what we were, of what we like or liked, they know nothing; and we -if that can be possible-know even less of them. Whether familiarity will breed contempt, or whether they will come home to our business and bosom-these are things that lie on the lap of the future.

But it is to be observed that the associations of old books, as of new books, are not always exclusively connected with their text or format,-are sometimes, as a matter of fact, independent of both. Often they are memorable to us by length of tenure, by propinquity, - even by their patience under neglect. We may never read them, and yet by reason of some wholly external and accidental characteristic, it would be a wrench to part with them if the moment of separation-the 'inevitable 
hour'-should come at last. Here, to give an instance in point, is a stained and battered French folio, with patched corners,-Mons. N. Renouard's translation of the 'Metamorphoses d'Ovide,' 1637 , enrichies de figures d chacune fable (very odd figures some of them are !), and to be bought chez Pierre Billaine, rue St. Facques, d la Bonne Foy, devant St. Ives. It has held no honoured place upon the shelves; it has even resided au rez de chaussee, -that is to say, upon the floor; but it is not less dear, - not less desirable. For at the back of the 'Dedication to the King' (Lewis XIII., to wit) is scrawled in a slanting, irregular hand: 'Pour mademoiselle de mons Son tres humble et tres obeissant Serviteur St. Andre.' Between the fourth and fifth word, some one, in a writing of later date, has added par, and after St. Andre, the signature Vandeuvre. In these impertinent interpolations I take no interest. But who was Mlle. de Mons? As Frederick Locker sings :

'Did She live yesterday or ages back?

What colour were the eyes when bright and waking? And were your ringlets fair, or brown, or black,

Poor little Head! that long has done with aching!' ' 'Ages back' she certainly did not live, for the book is dated ' 1637 ', and 'yesterday' is absurd. But

I This quatrain has the distinction of having been touched upon by Thackeray. When Mr. Locker's manuscript went to the 'Cornhill Magazine' in 1860, it ran thus:

- Did she live yesterday, or ages sped?

What colour were the eyes when bright and waking? And were your ringlets fair? Poor little head I

Poor little heart! that long has done with aching!' 


\section{I34 ON SOME BOOKS AND}

that her eyes were bright, - nay, that they were unusually lively and vivacious, even as they are in the sanguine sketches of $M$. Antoine Watteau a hundred years after, I am 'confidous'-as Mrs. Slipslop would say. For my theory (in reality a foregone conviction which I shrink from disturbing) is, that Mlle. de Mons was some delightful seventeenth-century French child to whom the big volume had been presented as a picture-book. I can imagine the alert, strait-corsetted little figure, with ribboned hair, eagerly craning across the tall folio; and following curiously with her finger the legends under the copper 'figures,'- ' Narcisse en fleur,' 'Ascalaphe en hibou,' 'Jason endormant le dragon,'- and so forth, with much the same wonder that the Sinne-Beelden of 'Vader Cats' stirred in the little Dutchwomen of Middleburgh, or that filled the child Charles Lamb when he peered at the 'Witch of Endor page' in Stackhouse's ' History of the Bible.' There can be no Mlle. de Mons but this, and for me she can never grow old!

Sometimes it comes to pass that the association is of a more far-fetched and fanciful kind. In the great 'Ovid' it lies in an inscription : in my next case it is 'another guess matter.' The folio this time is the 'Sylva Sylvarum' of the Right Hon. Francis, Lo. Verulam, Viscount St. Alban, whom some people still speak of as Lord Bacon. 'Tis only the 'sixt Edition;' but it was to be bought at the Great Turk's Head, 'next to the Mytre Taverne' (not the modern pretender, be it observed), which is in itself a feature of interest. A former possessor, from his notes, appears to have been largely pre- 
occupied with that ignoble clinging to life which so exercised Matthew Arnold, for they relate chiefly to laxative simples for medicine; and he comforts himself, in April, I695, by transcribing Bacon's reflection that 'a life led in Religion and in Holy Exercises' conduces to Longevity, - an aphorism which, however useful as an argument for length of days, is a rather remote reason for religion. But what to me is always most seductive in the book is, that to this edition (not copy, of course) of $165^{\circ}$ Master Izaak Walton, when he came, in his ' Compleat Angler' of 1653 , to discuss such abstraet questions as the transmission of sound under water, and the ages of carp and pike, must probably have referred. He often mentions 'Sir Francis Bacon's' 'History of Life and Death,' which is included in the volume. No doubt it would be more reasonable and more 'congruous' that Bacon's book should suggest Bacon. But there it is. That illogical 'succession of ideas' which puzzled my Uncle Toby, invariably recalls to me, not the imposing folio to be purchased 'next to the Mytre Taverne' in Fleet Street, but the unpretentious eighteen-penny octavo which, three years later, was on sale at Marriot's in St. Dunstan's churchyard hard by, and did no more than borrow its 'scatter'd sapience' from the riches of the Baconian storehouse.

Life, and its prolongation, is again the theme of the next book (also mentioned, by the way, in Walton) which I take up, though unhappily it has no inscription. It is a little old calf-clad copy of Cornaro's 'Sure and Certain Methods of Attaining a long and healthful Life,' 4th ed., 24mo, 1727; 
and was bought at the Bewick sale of February, 1884 , as having once belonged to Robert Elliot Bewick, only son of the famous old Newcastle woodengraver. As will be shown later, it is easy to be misled in these matters, but I cannot help believing this volume, which looks as if it had been re-bound, is the one to which Thomas Bewick refers in his 'Memoir' as having been his companion in those speculative wanderings over the Town Moor or the Elswick Fields, when, as an apprentice, he planned his future $d$ la Franklin, and devised schemes for his conduct in life. In attaining Cornaro's tale or years he did not succeed; though he seems to have faithfully practised the periods of abstinence enjoined (but not observed) by another of the "noble Venetian's' professed admirers, Mr. Addison of the 'Spectator.'

If I have admitted a momentary misgiving as to the authenticity of the foregoing relic of the "father of white line,' there can be none about the next item to which I now come. Once, on a Westminster bookstall, long since disappeared, I found a copy of a seventh edition of the 'Pursuits of Literature' of T. J. Mathias, Queen Charlotte's Treasurer's Clerk. Ruthlessly cut down by the binder, that durus arator had unexpectedly spared a solitary page for its manuscript comment, which was thoughtfully turned up and folded in. It was a note to this couplet in Mathias, his Dialogue II. :

'From Bewick's magick wood throw borrow'd rays O'er many a page in gorgeous Bulmer's blaze,-' : 'gorgeous Bulmer' (the epithet is unhappy!) being 
the William Bulmer who, in 1795, issued the 'Poems of Goldsmith and Parnell.'

'I ' (says the writer of the MS. note) ' was chiefly instrumental to this ingenious artist's [Bewick's] excellence in this art. I first initiated his master, Mr. Ra. Beilby (of Newcastle) into the art, and his first essay was the execution of the cuts in my Treatise on Mensuration, printed in 4to, 1770. Soon after I recommended the same artist to execute the cuts to Dr. Horsley's edition of the works of Newton. Accordingly Mr. B. had the job, who put them into the hands of his assistant Mr. Bewick, who executed them as his first work in wood, and that in a most elegant manner, tho' spoiled in the printing by John Nichols, the Black-letter printer. C.H. 1798.'

'C.H.' is Dr. Charles Hutton, the Woolwich mathematician. His note is a little in the vaunting vein of that 'founder of fortun's,' the excellent Uncle Pumblechook of ' Great Expectations,' for his services scarcely amounted to 'initiating' Bewick or his master into the art of engraving on wood. Moreover, his memory must have failed him, for Bewick, and not Beilby, did the majority of the cuts to the 'Mensuration,' including a much-praised diagram of the tower of St. Nicholas Church at Newcastle, afterwards often a familiar object in the younger man's designs and tail-pieces. Be this as it may, Dr. Hutton's note was surely worth saving from the pitiless binder's plough.

Between the work of Thomas Bewick and the work of Samuel Pepys, it is idle to attempt any ingenious connecting link, save the fact that they both wrote autobiographically. The 'Pepys' in question here, however, is not the famous 'Diary,' but the 
Secretary to the Admiralty's 'only other acknowledged work,' namely, the privately printed 'Memoires Relating to the State of the Royal Navy of England, for Ten Years,' I 690; and this particular copy may undoubtedly lay claim to exceptional interest. For not only does it comprise those manuscript corrections in the author's handwriting, which Dr. Tanner reproduces in his excellent Clarendon Press reprint of last year, but it includes the two portrait plates of Robert White after Kneller. The larger is bound in as a frontispiece; the smaller (the book-plate) is inserted at the beginning. The chief attraction of the book to me, however, is its previous owners-one especially. My immediate predecessor was a well-known collector, Professor Edward Solly, at whose sale in $1886 \mathrm{I}$ bought it; and he in his turn had acquired it in 1877 , at Dr. Rimbault's sale. Probably what drew us all to the little volume was not so much its disclosure of the lamentable state of the Caroline navy, and of the monstrous toadstools that flourished so freely in the ill-ventilated holds of His Majesty's ships-of-war, as the fact that it had once belonged to that brave old philanthropist, Captain Thomas Coram of the Foundling Hospital. To him it was presented in March, 1723 , by one C. Jackson; and he afterwards handed it on to a Mr. Mills. Pasted at the end of the book is Coram's autograph letter, dated 'June 1oth, 1746.' -To Mr. Mills These. Worthy Sir I happend to find among my few Books Mr. Pepys his memoires, wch I thought might be acceptable to you \& therefore pray you to accept of it. I am $w^{\text {th }}$ much Respect Sir your most humble Sert. Thomas Coram.' 
At the Foundling Hospital is a magnificent fulllength of Coram, with curling white locks and kindly, weather-beaten face, from the brush of his friend and admirer, William Hogarth. It is to Hogarth and his fellow-Governor at the Foundling, John Wilkes, that my next jotting relates. These strange colleagues in charity - as is well known-afterwards quarrelled bitterly over politics. Hogarth caricatured Wilkes in the 'Times': Wilkes replied by a 'North Briton' article (No. I7) so scurrilous and malignant that Hogarth was stung into rejoining with that famous squint-eyed semblance of his former crony, which has handed him down to posterity more securely than the portraits of Zoffany and Earlom. Wilkes's action upon this was to reprint his article with the addition of a bulbousnosed woodcut of Hogarth 'from the Life.' These facts lent piquancy to an entry which for years had been familiar to me in the Sale Catalogue of Mr. H. P. Standly, and which ran thus: "The "North Briton," No. 17, with a Portrait of Hogarth, in wood; and a severe critique on some of his works : in Ireland's handwriting is the following-" This paper was given to me by Mrs. Hogarth, Aug. 1782, and is the identical North Briton purchased by Hogarth, and carried in his pocket many days to show his friends." The Ireland referred to (as will presently appear) was Samuel Ireland of the 'Graphic Illustrations.' When, in 1892 , dispersed items of the famous Joly collection began to appear sporadically in the second-hand catalogues, I found in that of a well-known London bookseller, an entry plainly 
describing this one, and proclaiming that it came "from the celebrated collection of Mr. Standly, of St. Neots.' Unfortunately, the scrap of -paper connecting it with Mrs. Hogarth's present to Ireland had been destroyed. Nevertheless I secured my prize; had it fittingly bound up with the original number which accompanied it; and here and there, in writing about Hogarth, bragged consequentially about my fortunate acquisition. Then came a day - a day to be marked with a black stone!-when in the British Museum Print Room, and looking through the '__ Collection,' for the moment deposited there, I came upon another copy of the 'North Briton,' bearing in Samuel Ireland's writing a notification to the effect that it was the identical No. '17, etc. etc. Now, which is the right one? Is either the right one? I inspect mine distrustfully. It is soiled, and has evidently been folded; it is scribbled with calculations; it has all the aspect of a 'vénérable vétusté.' That it came from the Standly collection, I have not the slightest doubt. But that other pretender in the (now dispersed) '—_ Collection'? And was not Samuel Ireland (nomen invisum !) the, if not fraudulent, at least too-credulous father of one' William Henry Ireland, who, at eighteen, wrote 'Vortigern and Rowena,' and palmed it off as Shakespeare? I fear me-I much fear me-that, in the words of the American showman, I have been 'weeping over the wrong grave.'

It would not be difficult to prolong these vagrant adversaria. Here, for example, dated 1779, are the 'Coplas' of the poet Don Jorge Manrique, 
which, having no Spanish, I am constrained to study in the renderings of Longfellow. Don Jorge was a Spaniard of the Spaniards, Commendadór of Montizon, Knight of the Order of Santiago, Captain of a company in the Guards of Castille, and withal a valiant soldado, who died of a wound received in battle. But the attraction of my copy is, that, at the foot of the title-page, in beautiful neat script, appear the words, 'Robert Southey. Paris. I7 May I 817,' being the year in which Southey stayed at Como with Walter Savage Landor. Here is the chronicle of another 'ingenious hidalgo,' the 'Don Quixote' of Shelton, I652, where, among other names with which it is liberally overscrawled, occurs that of Lackington the bookseller, whose queer 'Memoirs' and 'Confessions' still keep a faded interest. Here again is an edition (the first) of Hazlitt's 'Lectures on the English Comic Writers,' annotated copiously in MS. by a contemporary reader who was certainly not an admirer; and upon whom W. H.'s cockneyisms, Gallicisms, egotisms, and 'ille-isms' generally, seem to have had the effect of a red rag upon a particularly insular bull. 'A very ingenious but pert, dogmatical, and Prejudiced Writer'-is the unflattering addition to the author's name on the title-page. Then here is Cunningham's 'Goldsmith,' of 1854 , vol. i., castigated with equal energy by that egregious Alaric A. Watts, of whose comments upon Wordsworth we read not long since in the 'Cornhill Magazine,' and who will not allow Goldsmith to say, in the 'Haunch of Venison,' " the porter and ${ }_{10}$ e eatables followed behind.' 'They could scarcely 


\section{ON SOME BOOKS.}

have followed before,' he objects, in the very accents of Bocotia. Nor will he pass 'the hollowsounding bittern' of the 'Deserted Village.' A barrel may sound hollow, but not a bird, according to this sagacious critic. Had the gifted author of 'Lyrics of the Heart' never heard of rhetorical figures? But his strenuous editorial efforts might well furnish forth a separate paper. Which reminds me that this one already grows too long; and justifies me in bringing it abruptly to a close.

Austin Dobson. 